Journal of Animal and Veterinary Advances 9 (12): 1785-1790, 2010

ISSN: $1680-5593$

(C) Medwell Journals, 2010

\title{
Effects of Different Levels of Effective Fiber in Close-up Cows Diets on Intake and Chewing Activity and Subsequent Lactation Performance in Holstein Dairy Cows
}

\author{
${ }^{1}$ V. Keshavarz, ${ }^{1} \mathrm{H}$. Amanlou, ${ }^{2}$ A. Nikkhah, ${ }^{2} \mathrm{M}$. Dehghan Banadaky, \\ ${ }^{1}$ E. Mahjoubi and ${ }^{2} \mathrm{M}$. Kazemi Bonchenari \\ ${ }^{1}$ Department of Animal Science, College of Agriculture, University of Zanjan, Zanjan, Iran \\ ${ }^{2}$ Department of Animal Science, University College of Agriculture and Natural Resources, \\ University of Tehran, 31587-77871 Karaj, Iran
}

\begin{abstract}
The 18 multiparous close-up Holstein dairy cows averaging BW $791.1(\mathrm{SD}=44.72)$ in 23 day $(\mathrm{SD}=6)$ before expected calving date were assigned in a completely randomized design $(\mathrm{n}=6)$ to study the effects of different levels of effective fiber on chewing activity, intake and nutrients digestibility in close-up and performance in the subsequent lactation. The effective fiber was considered as high 30.40 , moderate 27.38 and low $24.61 \%$ for treatments $\mathrm{H}, \mathrm{M}$ and L, respectively. All the cows were fed the same diet after parturition until 20 days in milk. Total chewing activity negatively affected by decreasing the effective fiber content in the diet. Total rumination time was 473,443 and $408 \mathrm{~min}^{-1 a y}{ }^{-1}$ for treatments $\mathrm{H}, \mathrm{M}$ and L, respectively $(\mathrm{p}<0.03)$. Pre-calving DMI was $12.07,14.29$ and $12.89 \mathrm{~kg} \mathrm{day}^{-1},(\mathrm{p}<0.0007)$ and post-calving DMI was $17.41,19.03$ and 18.72 for treatments $\mathrm{H}, \mathrm{M}$ and $\mathrm{L}$, respectively $(\mathrm{p}<0.0001$ ). Milk yield $(\mathrm{p}<0.09)$ and milk protein yield $(\mathrm{p}<0.07)$ were tended to rise with decreasing the effective fiber but there was no effect on milk fat yield among treatments. The results showed that decreasing the effective fiber in close-up diets increased DMI in both pre and post calving. It was concluded that although the strategy of decreasing effective fiber content of the close-up diets increases DMI and improved energy balance in dairy cows, the severe decrease of effective fiber in close-up diets could negatively affect rumination time that possibly could have negative effects on cow health.
\end{abstract}

Key words: Effective fiber, dry matter intake, transition period, holstein dairy cows, rumination, post-calving

\section{INTRODUCTION}

Nutritional management and metabolism of the transition dairy cow have been extensively studied in recent years (Overton and Waldron, 2004; Doepel et al., 2009). Dry Matter Intake (DMI) is one of the most important concerning topics in transition cow nutrition program. The DMI is decreased about $30 \%$ pre calving and also it will be $20 \%$ less after calving rather than the peak of milk production time (Friggens et al., 2007). Because of the high demands of nutrients after calving for milk production, lower DMI could not cover the requirements; therefore reserved fats are mobilized to liver to supply the energy and in this situation the cows are susceptible to develop fatty liver (Doepel et al., 2009). One of the main goals of the close-up diets is to maximize DMI in the subsequent lactation period to support high energy demand for early lactation (Doepel et al. 2009). Moreover, increasing DMI pre parturient could be useful tool for decreasing the metabolic disorders in dairy cows (Overton and Waldron, 2004). The fiber content of the feed is one of the most important factors related to intake in dairy cows (Grummer et al., 2004). Feeding the dairy cows with 30,42 and $54 \%$ of NDF, Grummer et al. (2004) concluded that DMI of the cows will be 2.03, 1.68 and $1.64 \%$ of body weight respectively. Physically effective Neutral Detergent Fiber (peNDF) is a part of NDF which stimulates the chewing activity (Mertens, 1997). From the other hand decreasing the fiber content of the diet caused to make lower ruminal $\mathrm{pH}$ which damages the surface of rumen wall causing the ulceration of the epithelium (Krause and Otzel, 2006).

Once the ruminal epithelium is damaged, bacteria enter portal circulation causing the liver abscesses and an inflammatory response (Gozho et al., 2005) which could have negative effects in transitional dairy cows (Overton and Waldron, 2004). Although, there are recommendations of Effective Neutral Detergent Fiber (eNDF) and peNDF for high producing dairy cows, the requirements of these parameters have not been considered extensively around calving. In this study the effects of different levels of effective fiber on pre calving

Corresponding Author: Mehdi Kazemi Bonchenari, Department of Animal Science,

University College of Agriculture and Natural Resources, University of Tehran, 31587-77871 Karaj, Iran 
DMI, blood metabolites, chewing activity, nutrients digestibility and also on post calving blood metabolites and performance of Holstein dairy cows were investigated.

\section{MATERIALS AND METHODS}

Cows, management and diets: In the present study 18 multiparous close-up Holstein dairy cows averaging BW 791.1 ( $\mathrm{SD}=44.72)$ in 23 days $(\mathrm{SD}=6)$ before expected calving date at the beginning of the study were assigned in a completely randomized design $(\mathrm{n}=6)$. Three isonitrogenous diets differing in effective fiber contents were formulated with the NRC (2001) dairy ration formulation software. The effective fiber was high 30.40 , moderate 27.38 and low $24.61 \%$ which considered as treatments $H, M$ and $L$, respectively. Decreasing the effective fiber was gained by replacing the forage sources (alfalfa hay and corn silage) by barely grain. Feed ingredients and composition of three different diets are shown in Table 1. The cows were fed Total Mixed Ration (TMR) in grouping system at 08:00 and 16:00. Orts were collected and weights recorded once daily before morning feeding and the feeding rate were adjusted daily to yield orts of about $5-10 \%$ intake. The intake of the individuals was calculated through the total intake of each group divided by the number of the cows in group ( 6 cows per each group). The diet for all three groups of the cows was similar after calving until 20 days in milk. After calving the cows were fed TMR at 08:00 and 16:00 and calculating the individual DMI was same as the close-up period. Post calving diets also was formulated with NRC (2001) and based on DM\% was contained $40.3 \% \mathrm{NFC}, 31.2 \% \mathrm{NDF}$, $10.3 \% \mathrm{RDP}, 1.70 \mathrm{Mcal} \mathrm{kg}{ }^{-1}$ net energy for lactation $\left(\mathrm{NE}_{1}\right)$ and $17.2 \% \mathrm{CP}$ and was consisting of $453.3 \mathrm{~g} \mathrm{~kg}^{-1}$ forage (DM basis), comprised of $323.3 \mathrm{~g} \mathrm{~kg}^{-1}$ alfalfa hay and $130 \mathrm{~g} \mathrm{~kg}^{-1}$ corn silage. The composition of the concentrate (DM basis) was as follows: $300 \mathrm{~g} \mathrm{~kg}^{-1}$ barley grain, $20.8 \mathrm{~g} \mathrm{~kg}^{-1}$ corn grain, $25 \mathrm{~g} \mathrm{~kg}^{-1}$ cottonseed, $50 \mathrm{~g} \mathrm{~kg}^{-1}$ soybean meal, $18 \mathrm{~g} \mathrm{~kg}^{-1}$ fish meal, $40 \mathrm{~g} \mathrm{~kg}^{-1}$ canola meal, $16 \mathrm{~g} \mathrm{~kg}^{-1}$ tallow, $41.1 \mathrm{~g} \mathrm{~kg}^{-1}$ molasses, $3.9 \mathrm{~g} \mathrm{~kg}^{-1}$ salt, $12.6 \mathrm{~g} \mathrm{~kg}^{-1}$ sodium bicarbonate, $5.6 \mathrm{~g} \mathrm{~kg}^{-1}$ calcium carbonate, $1.1 \mathrm{~g} \mathrm{~kg}^{-1}$ oxide magnesium and $12.6 \mathrm{~g} \mathrm{~kg}^{-1}$ mineral and vitamin mixture. The cows were milked three times daily by $8 \mathrm{~h}$ intervals starting from 06:00. The cows had free access to water and salt block.

Experimental procedures and chemical analyses: The DM of the corn silage and alfalfa composites was determined by drying at $60^{\circ} \mathrm{C}$ for $48 \mathrm{~h}$ (AOAC, 1990). Intake of DM was computed based on the $60^{\circ} \mathrm{C}$ DM determinations for TMR and orts. After drying,
Table 1: Ingredients and chemical composition of pre calving experimental diets

\begin{tabular}{|c|c|c|c|}
\hline \multirow[b]{2}{*}{ Items } & \multicolumn{3}{|c|}{ Treatments ${ }^{1}$} \\
\hline & $\mathrm{H}$ & M & $\mathrm{L}$ \\
\hline \multicolumn{4}{|l|}{ Ingredients (DM\%) } \\
\hline Alfalfa hay (Chopped) & 32.00 & 28.00 & 24.00 \\
\hline Corn silage & 32.00 & 28.00 & 24.00 \\
\hline Barely (ground) & 2.00 & 10.00 & 18.00 \\
\hline Com (ground) & 7.00 & 7.00 & 7.00 \\
\hline Wheat (ground) & 3.00 & 3.00 & 3.00 \\
\hline Wheat bran & 3.00 & 3.00 & 3.00 \\
\hline Cottonseed meal & 5.50 & 5.50 & 5.50 \\
\hline Soybean meal & 11.00 & 11.00 & 11.00 \\
\hline Tallow & 0.30 & 0.30 & 0.30 \\
\hline Glycolan & 2.40 & 2.50 & 2.50 \\
\hline Vitamin supplement ${ }^{2}$ & 0.50 & 0.50 & 0.50 \\
\hline Mineral supplement ${ }^{2}$ & 0.51 & 0.51 & 0.51 \\
\hline Anionic supplement & 0.70 & 0.70 & 0.70 \\
\hline \multicolumn{4}{|l|}{ Chemical composition } \\
\hline $\mathrm{CP}(\mathrm{DM} \%)$ & 14.50 & 14.50 & 14.50 \\
\hline $\mathrm{RDP}(\mathrm{CP} \%)$ & 73.10 & 74.40 & 75.80 \\
\hline $\mathrm{NE}_{\mathrm{L}}\left(\mathrm{Mcal} \mathrm{kg}^{-1}\right)$ & 1.56 & 1.61 & 1.65 \\
\hline NDF (DM\%) & 37.70 & 35.50 & 33.40 \\
\hline Forage NDF (DM\%) & 30.50 & 26.70 & 22.90 \\
\hline Effective NDF (DM\%) & 30.40 & 27.38 & 24.61 \\
\hline $\mathrm{ADF}(\mathrm{DM} \%)$ & 25.70 & 23.60 & 21.50 \\
\hline NFC (DM\%) & 40.00 & 42.40 & 44.80 \\
\hline $\mathrm{Ca}(\mathrm{DM} \%)$ & 0.60 & 0.60 & 0.55 \\
\hline $\mathrm{P}(\mathrm{DM} \%)$ & 0.40 & 0.40 & 0.40 \\
\hline
\end{tabular}

${ }^{1}$ The effective fiber contents of the diets were $30.40,27.38$ and $24.61 \%$ for $\mathrm{H}, \mathrm{M}$ and $\mathrm{L}$ treatments, respectively, ${ }^{2}$ Composition: $1.6 \% \mathrm{Mn}, 1.8 \% \mathrm{Zn}$, $0.85 \% \mathrm{Fe}, 0.40 \% \mathrm{Cu}, 0.03 \% \mathrm{I}, 0.03 \% \mathrm{Co}, 0.01 \%$ Se. $5,000,000 \mathrm{IU} \mathrm{kg}^{-1}$ of vitamin $\mathrm{A}, 860,000 \mathrm{IU} \mathrm{kg}^{-1}$ of vitamin $\mathrm{D}, 5,500 \mathrm{IU} \mathrm{kg}^{-1}$ of vitamin $\mathrm{E}$

ingredients and TMR were ground through a $1 \mathrm{~mm}$ screen (Wiley mill, Arthur H. Thomas, Philadelphia, PA) and total composites were prepared by mixing equal DM. Composite samples were analyzed for total nitrogen, DM, ash and organic matter (AOAC, 1990), sequentially for NDF and ADF (Van Soest et al., 1991). Milk was sampled daily at three consecutive milking times until 20 days after calving and analyzed for fat, protein, lactose, SNF (CombiFoss 5000, Foss Electric, Hillerød, Denmark). Grab fecal samples were collected a week before expected calving date and the fecal composite of each cow was oven-dried at 55 for $72 \mathrm{~h}$ and then ground through a $1 \mathrm{~mm}$ sieve. After analyzing the fecal samples for nutrients, total tract apparent digestibility of nutrients was determined by using acid insoluble ash as an internal marker (Van Keulen and Young, 1977). The BW changes were measured at the 1st day, just after calving and the last day of experiment. At the same days for body weight recording, body condition score was measured based on the Wildman et al. (1982). The method of Penn State Particle Separator (PSPS) developed by Penn State University was used for particle size separation and measurement of the distribution of particle size in different sieves. Chewing activity (eating plus rumination) was determined for a period of $48 \mathrm{~h}$ with $10 \mathrm{~min}$ intervals (Yang and Beauchemin, 2006). Blood samples were collected in a week before expected calving on $3 \mathrm{~h}$ after 
morning feeding and a week after calving at the same time from coccygeal vein of the cows. Blood samples were heparinized and held at $2^{\circ} \mathrm{C}$ for about $6 \mathrm{~h}$. After being held samples were centrifuged $\left(3,000 \times \mathrm{g} 4^{\circ} \mathrm{C}, 20 \mathrm{~min}\right)$ and the plasma stored at $-20^{\circ} \mathrm{C}$ for later analysis. After thawing, the blood glucose, Nonesterified Fatty Acids (NEFA) and $\beta$-Hydroxybutyric Acid (BHBA) measured with commercial kits.

Statistical analysis: Data were analyzed using Proc Mixed in SAS Institute (2000). The following model was fitted the variables:

$$
Y_{i j}=\mu+T_{i}+Z_{j}+Z T_{i j}+\varepsilon_{i j}
$$

Where:

$\mathrm{y}_{\mathrm{ij}}=$ The dependent variable

$\mu=$ The overall mean

$\mathrm{T}_{\mathrm{i}}=$ The effect of treatment $\mathrm{i}$ (treatments $\mathrm{H}, \mathrm{M}$ and $\mathrm{L}$ )

$Z_{j}=$ The effect of time $j$

$\mathrm{Zt}_{\mathrm{ij}}=$ The interaction between time $\mathrm{j}$ and treatment $\mathrm{i}$

$\epsilon_{\mathrm{ij}}=$ The residual error

Differences between least squares means were considered significant at $\mathrm{p}<0.05$ and differences were considered to indicate a trend toward significance at $0.05<\mathrm{p}<0.10$.

\section{RESULTS AND DISCUSSION}

DMI and nutrients digestibility: Data for pre and post calving DMI and pre calving nutrients digestibility shown in Table 2. The DMI in both pre and post calving were significantly affected with treatments $(\mathrm{p}<0.01)$. The trend of DMI changes pre and post calving was similar to each other. Mashek and Beede (2001) showed that pre and post calving DMI has a high correlation. Decreasing the effective fiber in treatment $\mathrm{M}$ increased DMI in both pre and post calving. Greater decrease in effective fiber in treatment $\mathrm{L}$, decreased DMI compared with treatment Yang and Beauchemin (2006) clarified that increasing the consumption of Physically Effective Neutral Detergent Fiber (peNDF) and Effective Neutral Detergent Fiber (eNDF) decreases the intake of dairy cows. The high ratio of forage in diets cause to rumen fill effect and consequently slow passage rate will decrease DMI in dairy cows (Allen, 2000). From the other hand, treatment $\mathrm{L}$ has the lowest forage content which was expected to have the highest DMI among treatments but because of higher consumption of barely grain it has potential to produce more propionate in rumen and therefore more propionate could have negative effect on intake of DM (Allen, 2000). Except than NDF digestibility which tended to be decreased among treatments $(p<0.09)$, digestibility of nutrients did not show any effect by
Table 2: Least square means for pre calving DMI and nutrients digestibility and post calving DMI of dairy cows fed different levels of effective fiber content

\begin{tabular}{|c|c|c|c|c|c|}
\hline \multirow[b]{2}{*}{$\underline{\text { Items }}$} & \multicolumn{3}{|c|}{ Treatments ${ }^{1}$} & \multirow[b]{2}{*}{ SE } & \multirow[b]{2}{*}{$\mathrm{p}$-value } \\
\hline & $\mathrm{H}$ & $\mathrm{M}$ & $\mathrm{L}$ & & \\
\hline \multicolumn{6}{|l|}{ Pre calving } \\
\hline DMI (kg day $\left.{ }^{-1}\right)$ & $12.07^{\mathrm{b}}$ & $14.29^{\mathrm{a}}$ & $12.89^{b}$ & 0.32 & 0.0007 \\
\hline \multicolumn{6}{|c|}{ Nutrients digestibility (\%) } \\
\hline $\mathrm{DM}$ & 64.20 & 63.00 & 62.90 & 0.73 & 0.1500 \\
\hline $\mathrm{CP}$ & 62.20 & 63.10 & 63.60 & 0.91 & 0.5000 \\
\hline NDF & 48.40 & 46.00 & 45.20 & 1.04 & 0.0900 \\
\hline \multicolumn{6}{|l|}{ Post calving } \\
\hline DMI (kg day $\left.{ }^{-1}\right)$ & $17.41^{\mathrm{b}}$ & $19.03^{\mathrm{a}}$ & $18.72^{\mathrm{ab}}$ & 0.43 & 0.0001 \\
\hline
\end{tabular}

${ }_{a, b, c}$ Least squares means within the same row without a common superscript differ $(p<0.05)$, ${ }^{1}$ The effective fiber contents of the diets were $30.40,27.38$ and $24.61 \%$ for $\mathrm{H}, \mathrm{M}$ and $\mathrm{L}$ treatments, respectively

different effective fiber consumption. Higher DMI increases passage rate which could decrease digestibility of nutrients (Mertens, 2002). Therefore numerical decrease of NDF digestibility in treatment L compared with treatments $\mathrm{H}$ and $\mathrm{M}$ probably is related to probable higher passage rate that is caused by higher DMI.

Particle size distribution and chewing activity: Data related to particle size distribution and chewing activity are given in Table 3 . As the expectation, by replacing the forage source by barely grain, peNDF was decreased among treatments. Treatment $\mathrm{H}$ was contained the highest amount of large particle size (i.e., $>8 \mathrm{~mm}$ and $>19 \mathrm{~mm}$ ). By replacing the forages by barely physical coefficient of diets was decreased in both treatments $\mathrm{M}$ and $\mathrm{L}$ compared with treatment $\mathrm{H}$. Total eating time $\left(\mathrm{min} \mathrm{day}^{-1}\right)$ decreased by decreasing the effective fiber content $(\mathrm{p}<0.03)$.

Moreover total eating time based on $\mathrm{kg}$ DMI, $\mathrm{kg}$ NDF intake and NFC intake also were decreased by in treatment Phillips (2002) proposed that eating $1 \mathrm{~kg}$ of concentrates takes time about 3-4 vs. 30 min needed for $1 \mathrm{~kg}$ of forage.

Total rumination time was decreased in treatment $\mathrm{L}$. As Poppi et al. (1985) stated that the particles which are longer than $1.18 \mathrm{~mm}$ has slower passage rate through rumen and they had to be change to smaller particles via rumination. Based on this, the rumination time was higher in treatment $\mathrm{H}$ compared with treatments $\mathrm{M}$ and $\mathrm{L}$. Beauchemin (2007) revealed that eating time in a dairy cow is about 2-6 $\mathrm{h} \mathrm{day}^{-1}$ and for rumination is 3-9 $\mathrm{h} \mathrm{day}^{-1}$, therefore total time of chewing (eating plus rumination) will be about $14 \mathrm{~h} \mathrm{day}^{-1}$.

The results of the present study show that decreasing the effective fiber content of the diets in close-up diets decreased the chewing time. Probably the severe decrease of this parameter could negatively affect the cow health around calving. It is notable that lower rumination time also could be as a candidate for lower NDF digestibility reasons. Beauchemin (2007) clarified 
Table 3: Least square means for particle size distribution based on PSPS system and chewing activity of dairy cows fed different levels of effective fiber content Treatments

\begin{tabular}{|c|c|c|c|c|c|}
\hline \multirow[b]{2}{*}{ Items } & & & & \multirow[b]{2}{*}{ SE } & \multirow[b]{2}{*}{$\mathrm{p}$-value } \\
\hline & $\mathrm{H}$ & $\mathrm{M}$ & $\mathrm{L}$ & & \\
\hline \multicolumn{6}{|l|}{ Sieve (mm) } \\
\hline$>19$ & $11.90^{\mathrm{a}}$ & $8.30^{b}$ & $3.10^{c}$ & 0.47 & 0.0001 \\
\hline $8-19$ & $42.30^{\mathrm{a}}$ & $29.60^{b}$ & $19.20^{c}$ & 1.25 & 0.0001 \\
\hline $1.18-8$ & $34.10^{\circ}$ & $42.70^{\mathrm{b}}$ & $53.10^{\mathrm{a}}$ & 1.46 & 0.0001 \\
\hline$<1.18$ & $11.60^{b}$ & $19.30^{\mathrm{ab}}$ & $24.60^{\mathrm{a}}$ & 2.11 & 0.0050 \\
\hline Physically effective fiber (\%) & $33.30^{\mathrm{a}}$ & $28.60^{b}$ & $25.10^{c}$ & 0.73 & 0.0010 \\
\hline Physical effective coefficient & $0.88^{\mathrm{a}}$ & $0.80^{\mathrm{ab}}$ & $0.74^{b}$ & 0.02 & 0.0400 \\
\hline \multicolumn{6}{|l|}{ Eating activity } \\
\hline $\min$ day $^{-1}$ & $285.00^{\mathrm{a}}$ & $266.60^{b}$ & $226.70^{c}$ & 14.38 & 0.0300 \\
\hline $\min \mathrm{kg}^{-1} \mathrm{DMI}$ & $23.61^{\mathrm{a}}$ & $18.97^{\mathrm{ab}}$ & $16.31^{\mathrm{b}}$ & 1.11 & 0.0010 \\
\hline $\min \mathrm{kg}^{-1} \mathrm{NDF}$ intake & $62.63^{a}$ & $53.43^{\mathrm{ab}}$ & $48.82^{b}$ & 3.08 & 0.0100 \\
\hline $\operatorname{min~} \mathrm{kg}^{-1}$ eNDF intake & 78.34 & 69.27 & 66.26 & 3.96 & 0.0800 \\
\hline min $\mathrm{kg}^{-1} \mathrm{NFC}$ intake & $59.03^{\mathrm{a}}$ & $44.73^{\mathrm{b}}$ & $36.40^{c}$ & 2.7 & 0.0001 \\
\hline \multicolumn{6}{|l|}{ Rumination activity } \\
\hline $\min$ day $^{-1}$ & $473.30^{\mathrm{a}}$ & $443.30^{b}$ & $408.40^{c}$ & 1.18 & 0.0300 \\
\hline $\min \mathrm{kg}^{-1} \mathrm{DMI}$ & $39.22^{\mathrm{a}}$ & $31.53^{\mathrm{ab}}$ & $29.38^{b}$ & 1.18 & 0.0001 \\
\hline $\min \mathrm{kg}^{-1} \mathrm{NDF}$ intake & $104.20^{\mathrm{a}}$ & $88.80^{\mathrm{b}}$ & $87.95^{c}$ & 3.30 & 0.0050 \\
\hline $\min \mathrm{kg}^{-1} \mathrm{eNDF}$ intake & $130.10^{\mathrm{a}}$ & $115.20^{\mathrm{ab}}$ & $119.40^{b}$ & 4.29 & 0.0500 \\
\hline $\min \mathrm{kg}^{-1} \mathrm{NFC}$ intake & $21.50^{\mathrm{a}}$ & $14.90^{\mathrm{b}}$ & $14.10^{b}$ & 0.61 & 0.0001 \\
\hline \multicolumn{6}{|l|}{ Chewing activity } \\
\hline $\min$ day $^{-1}$ & $758.30^{\mathrm{a}}$ & $710.10^{b}$ & $635.80^{\mathrm{c}}$ & 15.71 & 0.0002 \\
\hline $\min \mathrm{kg}^{-1} \mathrm{DMI}$ & $62.80^{a}$ & $50.50^{\mathrm{b}}$ & $45.60^{b}$ & 1.22 & 0.0001 \\
\hline $\min \mathrm{kg}^{-1} \mathrm{NDF}$ intake & $166.60^{\mathrm{a}}$ & $142.20^{b}$ & $136.70^{c}$ & 3.38 & 0.0001 \\
\hline min $\mathrm{kg}^{-1}$ eNDF intake & $208.40^{\mathrm{a}}$ & $184.40^{b}$ & $185.60^{\mathrm{b}}$ & 4.38 & 0.0020 \\
\hline $\min \mathrm{kg}^{-1} \mathrm{NFC}$ intake & $157.10^{\mathrm{a}}$ & $119.10^{b}$ & $101.90^{\mathrm{c}}$ & 2.94 & 0.0001 \\
\hline
\end{tabular}

${ }_{a, b, c}$ Least squares means within the same row without a common superscript differ $(p<0.05),{ }^{1}$ the effective fiber contents of the diets were $30.40,27.38$ and $24.61 \%$ for $\mathrm{H}, \mathrm{M}$ and $\mathrm{L}$ treatments, respectively

Table 4: Least square means for plasma metabolites of dairy cows fed different levels of effective fiber content

\begin{tabular}{|c|c|c|c|c|c|}
\hline \multirow[b]{2}{*}{ Items } & \multicolumn{3}{|c|}{ Treatments $^{1}$} & \multirow[b]{2}{*}{ SE } & \multirow[b]{2}{*}{$\mathrm{p}$-value } \\
\hline & $\mathrm{H}$ & M & $\mathrm{L}$ & & \\
\hline \multicolumn{6}{|l|}{ Pre calving } \\
\hline Glucose (mg dL $\left.{ }^{-1}\right)$ & $52.33^{b}$ & $62.83^{\mathrm{ab}}$ & $68.10^{\mathrm{a}}$ & 3.30 & 0.01 \\
\hline NEFA $\left(\mathrm{mmol} \mathrm{L}^{-1}\right)$ & 0.56 & 0.44 & 0.40 & 0.08 & 0.43 \\
\hline $\mathrm{BHBA}\left(\mathrm{mmol} \mathrm{L}^{-1}\right)$ & 0.47 & 0.43 & 0.42 & 0.06 & 0.86 \\
\hline \multicolumn{6}{|l|}{ Post calving } \\
\hline Glucose $\left(\mathrm{mg} \mathrm{dL}^{-1}\right)$ & $49.83^{b}$ & $58.33^{b}$ & $58.83^{\mathrm{a}}$ & 1.12 & 0.0001 \\
\hline NEFA $\left(\mathrm{mmol} \mathrm{L}^{-1}\right)$ & 1.05 & 0.81 & 0.71 & 0.10 & 0.09 \\
\hline BHBA $\left(\mathrm{mmol} \mathrm{L}^{-1}\right)$ & 1.14 & 0.93 & 0.80 & 0.11 & 0.10 \\
\hline
\end{tabular}

$a, b, c$ Least squares means within the same row without a common superscript differ $\left(\mathrm{p}<0.05\right.$ ), ${ }^{1}$ The effective fiber contents of the diets were $30.40,27.38$ and $24.61 \%$ for $\mathrm{H}, \mathrm{M}$ and $\mathrm{L}$ treatments, respectively

that lower rumination time could negatively affect NDF digestibility through decreasing the rumen $\mathrm{pH}$ because cellulolytic ruminal bacteria have slower growth rate in lower ruminal $\mathrm{pH}$ becaused by lower rumination time.

Blood metabolites: Among the blood metabolites only glucose concentrations in both pre and post calving significantly affected by treatments (Table 4). The NEFA concentration in post calving samples tended to rise $(\mathrm{p}<0.09)$. The treatment with lower effective fiber expected to produce greater propionate in rumen and consequently propionate is a main precursor of glucose in dairy cows (Dewhurst et al., 2000). Therefore increase of glucose in treatments $\mathrm{M}$ and $\mathrm{L}$ compared to treatment $\mathrm{H}$ could be a result of higher non fiber carbohydrate consumption. Treatment $\mathrm{H}$ has the lowest DMI and it could be concluded that because of 1 ower DMI, lower energy is
Table 5: Least square means for performance of dairy cows fed different levels of effective fiber content

\begin{tabular}{|c|c|c|c|c|c|}
\hline \multirow[b]{2}{*}{ Items } & \multicolumn{4}{|c|}{ Treatments $^{1}$} & \multirow[b]{2}{*}{$\mathrm{p}$-value } \\
\hline & $\mathrm{H}$ & $\mathrm{M}$ & $\mathrm{L}$ & SE & \\
\hline Milk yield (kg day $\left.{ }^{-1}\right)$ & 28.40 & 31.10 & 29.83 & 0.85 & 0.09 \\
\hline $\begin{array}{l}\text { Efficiency of DMI } \\
\text { (DMI/milk y ield) }\end{array}$ & 0.61 & 0.61 & 0.62 & 0.01 & 0.93 \\
\hline $4 \%$ FCM $\left(\mathrm{kg} \mathrm{day}^{-1}\right)$ & 26.42 & 27.58 & 25.89 & 1.06 & 0.48 \\
\hline Milk fat (\%) & 3.53 & 3.29 & 3.13 & 0.22 & 0.42 \\
\hline Milk fat $\left(\mathrm{kg}\right.$ day $\left.{ }^{-1}\right)$ & 1.00 & 1.02 & 0.93 & 0.06 & 0.57 \\
\hline Milk protein (\%) & 2.93 & 3.13 & 3.19 & 0.14 & 0.43 \\
\hline Milk protein $\left(\mathrm{kg} \mathrm{d}^{-1}\right)$ & 0.83 & 0.97 & 0.95 & 0.04 & 0.07 \\
\hline Lactose (\%) & 4.40 & 4.50 & 4.51 & 0.13 & 0.83 \\
\hline Lactose $\left(\mathrm{kg} \mathrm{day}^{-1}\right)$ & 1.25 & 1.40 & 1.34 & 0.06 & 0.24 \\
\hline Solids non fat (\%) & 8.38 & 8.72 & 8.60 & 0.18 & 0.44 \\
\hline Solids non fat kg day ${ }^{-1}$ & $2.38^{b}$ & $2.70^{\mathrm{a}}$ & $2.56^{\mathrm{ab}}$ & 0.07 & 0.02 \\
\hline $\begin{array}{l}\text { Body condition } \\
\text { score changes }\end{array}$ & -0.63 & -0.37 & -0.41 & 0.08 & 0.41 \\
\hline $\begin{array}{l}\text { Body weight } \\
\text { changes }(\mathrm{kg})\end{array}$ & -111.60 & 0133.30 & -106.30 & 21.20 & 0.17 \\
\hline
\end{tabular}

$a, b, c$ Least squares means within the same row without a common superscript differ $\left(p<0.05\right.$ ), ${ }^{1}$ The effective fiber contents of the diets were $30.40,27.38$ and $24.61 \%$ for $\mathrm{H}, \mathrm{M}$ and $\mathrm{L}$ treatments, respectively

supplied in this treatment. Based on this reason, it could be resulted that because of lower energy supplied in treatment $\mathrm{H}$, NEFA which is an indicator of energy balance in early lactating dairy cows had potential to be increased.

Post calving performance: The data for post calving performance of dairy cows were shown in Table 5 . There was a trend to increase for milk production among treatments by decreasing the effective fiber content 
$(\mathrm{p}<0.09)$. Not only greater DMI positively affected milk yield in treatments $\mathrm{M}$ and $\mathrm{L}$ but also higher capacity of absorption with lower forage fiber content could have positive effects on milk yield. As stated in NRC (2001), feeding fibrous diets before calving will decrease the rumen papillae growth and consequently the capacity of nutrients absorption negatively affect in the rumen. Therefore, it is probable that the cows in treatment $\mathrm{H}$ which fed high forage fiber content had the lowest capacity of nutrients absorption through rumen wall. Because the cows were fed with similar diets after calving, it is complicated to interpret the results of milk components in this study. Allen (1997) clarified that the milk fat did not respond to dietary changes in post calving time and body reserve mobilization make it complicated to interpret the effects of feed on milk components. In this study milk protein was tended to rise by increasing the effective fiber content in the $\operatorname{diet}(\mathrm{p}<0.07)$. Although protein content of diets was similar, protein intake was higher for treatments $\mathrm{N}$ and $\mathrm{L}$ because of greater DMI in these treatments compared with the treatment $\mathrm{H}$. Therefore greater protein intake caused to numerical increase of s protein content of milk.

From the other hand Huhtanen and Hristov (2009) recently showed that greater DMI could positively affect milk protein production probably via increasing microbial protein synthesis. Because of increase in milk protein content, the solids non fat affected significantly and increased with lower effective fiber consumption. Body weight changes and also body condition score changes of the cows did not show any significant difference among treatments. It seems that increased DMI caused to increase milk yield numerically and this difference was not effective enough to make a difference in body weights of the cows.

\section{CONCLUSION}

The results of the present study showed that decreasing effective fiber contents of dairy cows ration in close-up have positive effects on DMI in both pre and post calving times. Also milk yield was tended to rise in this study which clarifies the transitional effects of lower effective fiber contents of close-up diets on subsequent performance in dairy cows. Although, decreasing the effective fiber to $27.38 \%$ increased DMI, greater decrease of effective fiber to $24.61 \%$ tended to decrease fiber digestibility and dramatically decreased chewing activity that it is probable to have negative effects on dairy cow health.

\section{ACKNOWLEDGEMENTS}

The researchers thank to University of Zanjan for giving financial supports of the present study. Also they would like to express their regards to the laboratory works of $\mathrm{Mr}$ Sajedi the technician of animal nutrition laboratory in the University of Tehran.

\section{REFERENCES}

AOAC, 1990. Official Methods of Analysis. 15th Edn., Association of Official Analytical Chemists, Arlington, VA., USA.

Allen, M.S., 1997. Relationship between fermentation acid production in the rumen and the requirement for physically effective fiber. J. Dairy Sci., 80: 1447-1462.

Allen, M.S., 2000. Effects of diet on short-term regulation of feed intake by lactating dairy cows. J. Dairy Sci., 83: 1598-1624.

Beauchemin, K.A., 2007. Ruminal acidosis in dairy cows: Balancing physically effective fiber with starch availability. Proceedings of the Florida Ruminant Nutrition Symposium, Jan. 30-31, Best Western Gateway Grand Gainesville, FL., pp: 16-27.

Dewhurst, R.J., J.M. Moorby, M.S. Dhanoa, R.T. Evans and W.J. Fisher, 2000. Effects of altering energy and protein supply to dairy cows during the dry period. 1. Intake, body condition and milk production. J. Dairy Sci., 83: 1782-1794.

Doepel, L., G.E. Lobley, J.F. Bernier, P. Dubreuil and H. Lapierre, 2009. Differences in splanchnic metabolism between late gestation and early lactation dairy cows. J. Dairy Sci., 92: 3233-3243.

Friggens, N.C., P. Berg, P. Theilgaard, I.R. Korsgaard, K.L. Ingvartsen, P. Løvendahl and J. Jensen, 2007. Breed and parity effects on energy balance profiles through lactation: Evidence of genetically driven body energy change. J. Dairy Sci., 90: 5291-5305.

Gozho, G.N., J.C. Plaizier, D.O. Krause, A.D. Kennedy and K.M. Wittenberg, 2005. Subacute ruminal acidosis induces ruminal lipopolysaccharide endotoxin release and triggers an inflammatory response. J. Dairy Sci., 88: 1399-1403.

Grummer, R., D. Mashek and A. Hayirli, 2004. Dry matter intake and energy balance in the transition period. Vet. Clin. N. Am. Food Anim. Pract., 20: 447-470.

Huhtanen, P. and A.N. Hristov, 2009. A meta-analysis of the effects of dietary protein concentration and degradability on milk protein yield and milk $\mathrm{N}$ efficiency in dairy cows. J. Dairy Sci., 92: 3222-3232. 
Krause, M.K. and G.R. Otzel, 2006. Understanding and preventing subacute ruminal acidosis in dairy herds: A review. Anim. Feed Sci. Technol., 126: 215-236.

Mashek, D.G. and D.K. Beede, 2001 . Peripartum responses of dairy cows fed energy-dense diets for 3 or 6 weeks prepartum. J. Dairy Sci., 84: 115-125.

Mertens, D.R., 1997. Creating a system for meeting the fiber requirements of dairy cows. J. Dairy Sci., 80: 1463-1481.

Mertens, D.R., 2002. Measuring fiber and its effectiveness in ruminant diets. Proceedings of the Plains Nutritional Council Spring Conference, Mar. 29-30, San Antonio, Texas pp: 40-66.

NRC., 2001. Nutrient Requirements of Dairy Cattle. 7th Edn., National Academies Press, Washington, DC., USA., ISBN: 0309069971, pp: 381.

Overton, T.R. and M.R. Waldron, 2004. Nutritional management of transition dairy cows: Strategies to optimizemetabolic health. J. Dairy Sci., 87: E1 05-E119.

Phillips, C., 2002. Cattle Behavior and Welfare. 2nd Edn., Wiley-Blackwell Science, USA., ISBN-10: 0632056452 , pp: 272 .
Poppi, D.P., R.E. Hendrickson and D.J. Minson, 1985. The relative resistance to escape of leaf and stem particles from the rumen of cattle. J. Agric. Sci., 105: 9-14.

SAS Institute, 2000. SAS/STAT User's Guide, Version 8. SAS Inst. Inc., Cary, NC.

Van Keulen, J. and B.A. Young, 1977. Evaluation of acid-insoluble ash as a natural marker in ruminant digestibility studies. J. Anim. Sci., 44: 282-287.

Van Soest, P.J., J.B. Robertson and B.A. Lewis, 1991. Methods for dietary fiber, neutral detergent fiber and Nonstarch polysaccharides in relation to animal nutrition. J. Dairy Sci., 74: 3583-3597.

Wildman, E.E., G.M. Jones, P.E. Wagner, R.L. Boman, H.F. Troutt and T.N. Lesch, 1982. A dairy cow body condition scoring system and its relationship to selected production characteristics. J. Dairy Sci., 65: 495-561.

Yang, W.Z. and K.A. Beauchemin, 2006. Increasing the physically effective fiber content of dairy cow diets may lower efficiency of feed use. J. Dairy Sci., 89: 2694-2704. 